dens was not set up to tackle the famines. These would continue for more than a century, killing hundreds of thousands, and turning one-third of Bengal into a wasteland, before research was brought to bear on the problem.

Science returned to the scene of the famines with the setting up in 1880 of a 'scientific commission' of experts. The commission concluded that the problem would be better understood if each province contained a dedicated agricultural research department, and India's existing network of agricultural research centres was born. But Baber says that the scientists did not have it all their own way. Recommendations that could harm Britain's interests, such as one to reduce dependency on agriculture by developing industry in India, were ignored.

Meanwhile, the famines continued, wiping out all livestock and leaving 6 million people destitute in 1900. A new viceroy, George Curzon, was more determined than ever to apply science and technology to alleviating famine. Agricultural research was strengthened further. Pay and conditions for scientists were improved. And in 1902, Curzon took the additional step of setting up a Board of Scientific Advice to advise the government and coordinate research relating to the economy and agriculture.

This board, says Baber, "bore a striking resemblance to the 'Scientific Advisory Council' proposed for Britain three decades earlier by Alexander Strange, and Norman Lockyer". Lockyer, the first editor of Nature, was excited about the project, and covered the founding of the board in the journal $(67,568 ; 1903)$, as did some newspapers.

But the board did little to alleviate the famines, which appear to have ceased a few years before the end of empire. Baber believes that the colonial administrators knew full well that the famines had begun more than a century earlier as a result of an onerous tax burden, coupled to the neglect of irrigation systems. Science, deliberately or otherwise, proved a useful diversionary tactic.

In addition, the board's usefulness as an analogue for a similar committee in Britain remains debatable, given its inappropriately bureaucratic nature. The board's annual reports were communicated through the Secretary of State for India to the Royal Society. The society would then consult another advisory committee set up to liaise between the administrations in Britain and India. This committee would report back to the colonial office in India, providing any appropriate advice.

Both books contain many other examples of how institutions of science emerged during the colonial period in response to the political and economic problems of the day. Baber also attempts to provide information on science in ancient and mediaeval India. But, lacking access to good primary source material, his coverage contains little of the social and political context that so successfully illuminates his later chapters.

This, in a sense, brings us back to where we started. An understanding of the social context of science in different societies requires a mastery of history, science and language. The historiography of science in European colonial times is relatively easy to research, as most of the source material is well documented. An additional bonus for researchers from Europe and the United States is that it is in English. The development of science in non-Western empires, though, is more difficult to research.

Step back to before the sixteenth century, and the picture becomes hazy, as source material has yet to be properly catalogued. Some sociologists increasingly appear to want to pursue this research. But they lack the prerequisite training in language and history. On the other hand, the handful of those who have such skills - the professional historians of science - consider the pursuit of context to be a diversion from their job as historians. A meeting of minds is on few agendas.

This is unfortunate, as concerted cohabitation may one day lead to an assault on the one question that both groups are keen to answer: why did the scientific revolution happen in the West? Until this marriage takes place, we may never know.

Ehsan Masood is a science writer on Nature and is writing a book on the politics of science in Pakistan.

\section{A private function}

Why is Sex Fun? The Evolution of
Human Sexuality
by Jared Diamond
BasicBooks/Weidenfeld and Nicolson: 1997.
Pp. $168 . \$ 20, £ 11.99$
Alison Jolly

"Recreational sex and menopause were as important for our development of fire, language, art and writing as were our upright posture and large brains." Jared Diamond sets up a major claim at the start of Why is Sex Fun?. He then discusses not only recreational sex, but the evolutionary reasons why men philander more than women, whom it pays to desert first, why men don't breastfeed even though they could (and if in vitro fertilization keeps producing twins, perhaps will yet do so), and many other intriguing thoughts, ending with the overgrown human penis.

The author assumes no prior knowledge. Little of the story will surprise readers of the literature, or of Diamond's wonderful Third Chimpanzee (HarperCollins, 1992). But it is beautifully told, with male breast-feeding introducing a primer on embryonic sex differentiation, menopause one on life history strategy, and concealed ovulation the principle that evolution works on what is there.

Concealed ovulation and sex for fun may well have changed over time from the 'manyfathers' function, with troop males bamboozled into tolerating every infant as their own, to the opposite 'daddy-at-home' function of tribal males' paternal confidence, directed child-care and frequent sex with a loving maybe even monogamous - wife.

Diamond's recurrent ploy is to present his case, then add, "By now you are probably objecting that...". This lets him deal with counter-arguments while flattering the reader, who actually had only a dim feeling that there must be a catch somewhere. This book is simply written, but not simply thought out - it is a good book to leave around, half-hidden, to tempt teenage offspring to become biologists.

But what of Diamond's first big claim? He makes a clear case that monogamy within a community group, sex in private, menopause and our high parental investment are unique among our close primate kin. He does not quite sum up: there should be two pages more to pull the scenario together. Does he think that our unique sexual behaviour is itself what needs explaining, or is it an explanation?

Does he see a bipedal male australopithecine striding along like one of his New Guinea trackers, head high and hands free for defence against the genocidal males of the next group? And the female finding safety and paternal care more and more from a single mate as she evolves into early Homo, and focuses her extended sexual attractiveness from the many to the few, in private?

If this mating system accompanied the earliest expansion of the hominid brain, it would have provided a way for extended parental care to foster the slow growth of big-brained children (a familiar thought), while allowing an almost indefinitely expanded social group, which in turn would have demanded the brainpower of an expanding neocortex.

Diamond adds a factor much less often considered than the needs of children: the value of the old. A toothless crone who still recalls the famine food she ate after the hurricane of 1910 becomes both the tribal university library and their spaceship survival manual. Are longevity and menopause not just the result of bigger brains? Perhaps they evolved simultaneously or were even prerequisites? And how does this accord with Diamond's own preference for a 'big bang' emergence of language, art and religion a mere 30,000 years ago? Perhaps he should now write his missing two-page scenario.

Alison Jolly is in the Department of Ecology and Evolutionary Biology, Princeton University,

Princeton, New Jersey 08544-1003, USA. 